\title{
APARNA VAIDIK. Imperial Andamans: Colonial Encounter and Island History
}

\section{Journal Article}

\section{Author(s):}

Fischer-Tiné, Harald

Publication date:

2013-10

Permanent link:

https://doi.org/10.3929/ethz-b-000073929

Rights / license:

In Copyright - Non-Commercial Use Permitted

Originally published in:

The American historical review 118(4), https://doi.org/10.1093/ahr/118.4.1169 
Indian development but also Britain's economic interests including the welfare of British capital in India. These policies hurt the interests and aspirations of Indian business. The argument of the book is that the Indian bourgeoisie, when it acquired sufficient economic strength, became more vocal in challenging British policy in India that had been inimical to it all along.

The battle intensified in the interwar years. It was complicated, however, by three developments. First, until World War I India was valued by the empire for its commercial importance; after the war India became central to military strategy. The shift favored some Indian industries, such as steel, but the positive effect was neither deep nor lasting. Second, London and Delhi, the two axes deciding British policy in India, disagreed frequently, which made business response to the state ambiguous at times. Third, the relationship of business to Congress leadership was fraught because the Congress was subject to divergent pulls on economic issues. Mohandas K. Gandhi's preference for village crafts and Jawaharlal Nehru's preference for Soviet-style industrialization were not mutually compatible, and neither vision allowed a large role to capitalist industry. But all lobbies, including the rising Left, agreed on protection from foreign trade and capital, and this suited Indian capitalists. They tolerated, even supported, Nehru's socialism at the cost of dissension in the ranks. Little did they realize that while battling the monster of colonialism, they were helping to create a new monster. By the 1970 s, the socialistic state had grown so big and so restrictive that it stifled the bourgeoisie.

Much of the ground covered in the book has been covered in the already quite large literature on the subject. Nevertheless, the book has a refreshing quality. It tells its story directly, without jargons or polemics, and at times with insight. It is well researched too. For example, the two world wars and strategic considerations are dealt with more thoroughly and convincingly here than in other general treatments of the business history of late colonial India.

The conceptual framework adopted, however, is disputable. In Lockwood's neo-Marxist dependency-type analysis, the British Empire is seen as a state run by foreigners and working to serve foreign interests. Indian capitalists were compelled to challenge the domination. True, disagreements within the Congress or between London and Delhi add complications, but not enough to change the story. This story has been told before by leftist historians and pro-Congress ideologues in India. Lockwood recounts it better but does not change it. Is he persuasive?

Critics would argue that the narrative is flawed. We can neither define the empire unambiguously as a foreigner-ruled state nor can we understand capitalist attitudes without studying market conditions. In an alternative story, the empire mattered to capitalists not only as a state but also as an integrated international market for commodities, labor, and capital. Indian businesses wanted the empire as long as this marketplace served them. Few, if any, Indian merchant of the nineteenth century regretted colonial rule, because they profited from the connections forged by the empire. Bombay's merchants exported cotton to Liverpool, sold opium and cotton yarn in Hong Kong, and imported textile machines and foremen from Manchester. Calcutta's Marwari merchants, who included the nationalist Ghanshyam Das Birla, were dependent on the custom of the European managing agency houses. The collapse of the world economy in the interwar period ended many of these relationships. It weakened the Europeans, empowered the Indians, and reduced the value of globalization for all. An alternative approach to business attitude toward politics would show how the empire once helped Indians make money and then stopped doing so. This alternative is not discussed in the book.

TIRTHANKAR ROY

London School of Economics and Political Science

ApARna VAIDIK. Imperial Andamans: Colonial Encounter and Island History. (Cambridge Imperial and PostColonial Studies.) New York: Palgrave Macmillan. 2010. Pp. xvii, 282. \$89.00.

Aparna Vaidik's monograph presents a longue durée history of the Andaman Islands from the late eighteenth century to the end of the colonial period in the 1940s. Mainly due to the fact that the islands were used by the British as a penal colony for almost a century, there has been no dearth of scholarship on the history of this isolated archipelago in the Indian Ocean. Earlier Indian nationalist historians have tended to focus on the fate of Indian elite "revolutionaries" incarcerated in the infamous cellular jail of Port Blair during the 1910 s and 1920 s, some of them even celebrating the Andamans as a mukti tirth or "freedom's pilgrim site" in memory of the sacrifice and heroism involved in India's independence struggle. By contrast, most recent studies, such as British historian Clare Anderson's Legible Bodies: Race, Criminality, and Colonialism in South Asia (2004), The Indian Uprising of 1857-8: Prisons, Prisoners, and Rebellion (2007), and Subaltern Lives: Biographies of Colonialism in the Indian Ocean World, 17901920 (2012) or Satadru Sen's monograph Disciplining Punishment: Colonialism and Convict Society in the Andaman Islands (2000), have focused largely on the subaltern victims of the penal regime established by the Raj. Both authors are strongly influenced by Foucauldian ideas of the archipel carcéral. Unlike both groups of scholars Vaidik wants to "undo the shackles" (p. 5) resulting from the fixation of island historians on the penal regime in the period of high imperialism. She seeks this liberation from hegemonic scholarly accounts by two means. First, she places the colonial history of the Andamans in a wider temporal framework, thus doing away with the aura of naturalness from the archipelagos "carceral" career. Second, and obviously inspired by the huge body of recent scholarship on the "tensions of empire," Vaidik attempts a mapping of the 
"internal inconsistencies, asymmetries and contestations inherent in colonialism" (p. 5).

The first two chapters depart most clearly from Sen's and Anderson's work. Vaidik starts by tracing the history of the image of the Andamans as home of anthropophagous "savages" that emerged from the early modern period onward. She subsequently situates the British annexation of the islands in the context of British naval policies in the Indian Ocean and argues that the discourse of civilizing savagery deployed to legitimate colonial conquest only served to cloak the real goals of British imperialism. Neither the ambition to "uplift" dark-skinned cannibals nor the desire to found a penal colony for Indian convicts led to the incorporation of the Andamans into the British Asian empire, but rather a more far-reaching strategy to dominate the Indian Ocean. The goal was to establish coaling stations and naval bases in strategically important places that would serve to protect British trade interests by suppressing piracy and keeping European rivals at bay.

Chapter three discusses the difficulties of "opening up" the islands for commercial use. According to Vaidik, the very isolation that rendered the Andamans attractive as a site for a penal colony posed logistical problems, making the islands unattractive from an economic point of view. A variety of "natural" factors ranging from the climate to the unruly nature of the aborigines was responsible for the failure of the initial project of turning the archipelago into a self-sufficient colony.

However, chapters four to seven reconstruct the establishment, development, and decline of the penal regime in great detail and thus run somewhat contrary to Vaidik's initial claim of shifting the historiographical focus away from the obsession with "disciplining punishment." Moreover, many of the issues discussed here-such as the problem of labor extraction-have already been treated exhaustively in Sen's work. That being said, it must be positively noted that Vaidik displays a great sensitivity for the loopholes of colonial networks of power, and as a result Imperial Andamans presents a much weaker colonial state than Disciplining Punishment. She interrogates the Foucauldian paradigm deployed by Sen and Anderson by placing a stronger emphasis on the successful subversion of colonial policies by subaltern actors and highlighting the agency of the convicts including putatively disempowered groups such as low-castes and women (pp. 145-156).

While the author has definitely produced an interesting and important island history based on sound empirical research, she is only moderately successful in achieving the ambitious revisionist goals she has set for herself. My slight disappointment with the book hence results mostly from the hiatus between the objectives articulated in the introduction and the rather conventional fare that is actually delivered. The poor copyediting and unusually high number of typos in Vaidik's volume certainly do not improve this mixed impression, although this should probably be blamed on the publisher and not on the author. There are, however, sev- eral criticisms that go a bit deeper. Firstly, the author lacks, at times, critical distance from the sources and thus reproduces colonial stereotypes. Therefore, the way in which Chinese laborers and their opium "excesses" are presented (p. 123) seems somewhat problematic to this reviewer. Moreover, it is hard to understand why a study that wishes to break away from both the "Indocentrism" and the fixation on colonial penology that have hitherto structured most of the research on the Andamans should devote barely ten of its 200odd pages to the aboriginal Andamanese. The fact that the indigenous population was decimated to the verge of extinction is mentioned in a single paragraph ( $\mathrm{p}$. 130). Sen's new book, Savagery and Colonialism in the Indian Ocean: Power, Pleasure, and the Andaman Islanders (2010), remedies this lacuna.

To be sure, Vaidik's study has some important points to make and certainly deserves to be read by scholars of colonialism, "oceanic history," and penal history. Yet, whether her approach is indeed suited to replace the "inadequate and in many ways problematic categories" (p. 189) used in the existing studies on the Andamans is open to debate, not least because she remains indebted to those categories herself.

HARALd Fischer-Tiné

Swiss Federal Institute of Technology, Zurich

\section{OCEANIA AND THE PACIFIC ISLANDS}

Ian W. McLean. Why Australia Prospered: The Shifting Sources of Economic Growth. (Princeton Economic History of the Western World.) Princeton, N.J.: Princeton University Press. 2013. Pp. xiv, 281. Cloth \$35.00, e-book $\$ 35.00$.

In a series of articles written over many years, Ian W. McLean has addressed the dual questions of how Australia attained high levels of prosperity less than a century after European settlement and why it has since remained amongst the wealthiest of nations. Although this book is not a comprehensive study of Australian economic history, it builds on this earlier body of work and brings together his answers to these questions. It is engagingly written, helped by the minimal use of technical material and the creation of counterfactual scenarios in several places. Most important of all is McLean's impressive use of the comparative approach. While arguing that Australia's path of development has been strongly shaped by international influences-immigration, investment, trade, and political institutions-he interrogates closely its performance relative to that of other specific nations to tease out national differences as well. These are appropriately selected in most cases: the role of differences in land ownership patterns and political institutions with Argentina, or the greater connection of Canada's timber and grain industries to manufacturing than Australia's wool and mining. However, New Zealand might have featured more strongly in the comparative story. 